LIVIA MAGLIĆ, Ph.D. ${ }^{1}$

(Corresponding author)

E-mail: livia@pfri.hr

TOMISLAV KRLJAN, M.Sc. ${ }^{1}$

E-mail: tomislav.krljan@uniri.hr

NEVEN GRUBIŠIĆ, Ph.D. ${ }^{1}$

E-mail: neven.grubisic@uniri.hr

LOVRO MAGLIĆ, Ph.D. ${ }^{1}$

E-mail: maglic@pfri.hr

${ }^{1}$ University of Rijeka

Faculty of Maritime Studies

Studentska 2, 51000 Rijeka, Croatia
Traffic Engineering Original Scientific Paper Submitted: 27 May 2020 Accepted: 4 Nov. 2020

\title{
ESTIMATING URBAN ROAD TRANSPORT VEHICLES EMISSIONS IN THE RIJEKA CITY STREETS
}

\begin{abstract}
The growing demand for private and public transport services in urban areas requires sophisticated approaches to achieve satisfactory mobility standards in urban areas. Some of the main problems in urban areas today are road congestions and consequently vehicle emissions. The aim of this paper is to propose a methodological approach for the estimation of vehicle emissions. The proposed methodology is based on two interrelated models. The first model is a microscopic simulation SUMO model which can be used to identify the most congested urban areas and roads with critical values of traffic parameters. The second model is the COPERT Street Level for estimating vehicle emissions. The proposed models were tested on the urban area of Rijeka. The results of the microscopic SUMO simulation model indicate six urban roads with the critical traffic flow parameters. On the basis of the six identified urban roads, an estimation of vehicle emissions was carried out for specific time periods: 2017, 2020, 2025, and 2030. According to the results of the second model, the urban road R20-21 was identified as the most polluted road in the urban district of Rije$k a$. The results indicate that over the period 2017-2030, CO emissions will be reduced on average by $57 \%$ on all observed urban roads, $\mathrm{CO}_{2}$ emissions by $20 \%$, and $P M$ emissions by $58 \%$, while the largest reduction of $65 \%$ will be in $\mathrm{NO}_{x}$ emissions.
\end{abstract}

\section{KEYWORDS}

microscopic SUMO model; COPERT Street Level model; vehicle emission estimation; sustainable urban transport.

\section{INTRODUCTION}

The rapid global economic growth together with urban development have led to aggressive urbanization and motorization in many developing countries since 1980, which has contributed significantly to the amount of vehicle-derived air pollution [1]. From all transportation systems, road transport is responsible for about $71 \%$ of greenhouse gas (GHG) emissions from transport. The report of the Intergovernmental Panel on Climate Change (IPCC) shows that $20-30 \%$ of total GHGs are released from urban transportation operation including passenger and freight transportation [2]. Carbon dioxide $\left(\mathrm{CO}_{2}\right)$ is one of the most significant greenhouse gases, accounting for about $65 \%$ of the total GHG emissions [3]. GHG emissions from transport are rising faster than any other economic sector; under a business as usual (BAU) scenario, global transport GHG emissions are expected to increase from 8 to 16 billion tones by 2050 [4]. Combustion of fossil fuels in vehicles leads to emissions in road transport, which are one of the most important sources of primary air pollutants [5]. It is well known that fossil fuel combustion generates the main pollutants: Nitrogen Oxides $\left(\mathrm{NO}_{\mathrm{x}}\right)$, Carbon Monoxide (CO), Sulfur Oxides $\left(\mathrm{SO}_{\mathrm{x}}\right.$ ), Volatile Organic Compounds (VOC), and Particular Matters (PM). According to a review of the Convention on Long-range Transboundary Air Pollution (CLRTAP) by the European Environment Agency (EEA), road transport is the most significant source of $\mathrm{NO}_{\mathrm{x}}, \mathrm{CO}$ and non-methane volatile organic components (NMVOC), and the second most important source of $\mathrm{PM}_{10}$ and $\mathrm{PM}_{2.5}$ emissions [6]. In Europe, the road transport sector accounts for $40 \%$ of total annual emissions for $\mathrm{NO}_{\mathrm{x}}$, $23 \%$ for $\mathrm{CO}, 13 \%$ for primary $\mathrm{PM}_{2.5}, 9 \%$ for primary $\mathrm{PM}_{10}$, and $11 \%$ for VOCs [7]. Accurate information of vehicle emissions in a city could be collected only by monitoring stations located at specific sites 
throughout a city. They are usually well monitored in major cities, but it remains difficult to determine emissions or air quality data at street level in most cities worldwide [8]. Although the monitoring stations collect reliable data, the number of monitoring stations in a specific city is usually limited due to high purchase price and maintenance expenses.

In recent years, several approaches have been developed to assess and measure the impact of road traffic on urban air pollution, but emission models are the most commonly used. These emission models can be categorized as models that require the following data: average speed of passenger vehicles (e.g. Computer Program for Road Emissions Calculation - COPERT, EMission FACtors - EMFAC), traffic situations (i.e., qualitative estimates of driving conditions, e.g. Manual Road Traffic Emission Factors (HBEFA)) and Vehicle Condition Data (e.g. Passenger Car and Heavy Duty Emissions Model-PHEM, Motor Vehicle Emulator-MOVES) [911]. COPERT is a commonly used emission model in Europe. Key estimation parameters in the COPERT model include fleet composition, average speed, average mileage, fuel parameters, load, and slope, among which is the default value of average mileage in case the parameter is missing from the estimate [12]. In the COPERT model, emission and consumption factors are modeled as a function of average vehicle speed. EMFAC is a computer model that can estimate emissions from all motor vehicles, such as passenger cars to heavy duty vehicles, operating on highways, and local roads in the years 2000 to 2050 operating in California $[10,11]$. It is used to calculate the present and the future of motor vehicle emission inventories within a state, airport, air pool, county, or project. Road Transport
Emission Factors (HBEFA) provide an emission factor for all current vehicle categories (passenger cars, light commercial vehicles, heavy vehicles, city buses, mopeds, and motorcycles), each divided into different categories, for the most different traffic situations. Emission factors for all regulated and, most importantly, unregulated pollutants are included, as well as fuel/energy and $\mathrm{CO}_{2}$ consumption [12]. PHEM is a computer model that estimates vehicle emissions based on an extensive European vehicle measurement; it covers passenger cars, light and heavy city buses of up to 40 tons, and semi-trailers [13]. MOVES is a United Nations Environmental Agency (EPA) emission model for mobile sources, designed for use on a national to project scale [12]. It can estimate emissions from mobile sources that cover widespread air pollution, greenhouse gases, and air toxics.

\section{MATERIALS AND METHODS}

This section illustrates the data, methods, and models adopted in this study to calculate vehicle emissions at street level in the city of Rijeka. The methodology of the conducted research is based on two implementation stages (Figure 1).

Regarding Figure 1, the first stage consists of designing the traffic model to establish the roads (streets) with the highest traffic flow in the city of Rijeka. The most frequent way to establish the roads with the highest traffic flow is to calculate the number of vehicles during peak hours. However, this approach is incomplete considering that the traffic flow of a certain road is influenced by other parameters, such as the number of lanes on the considered roads, number of bus stops, number of traffic lights and the length of the interval, number of pedestrians

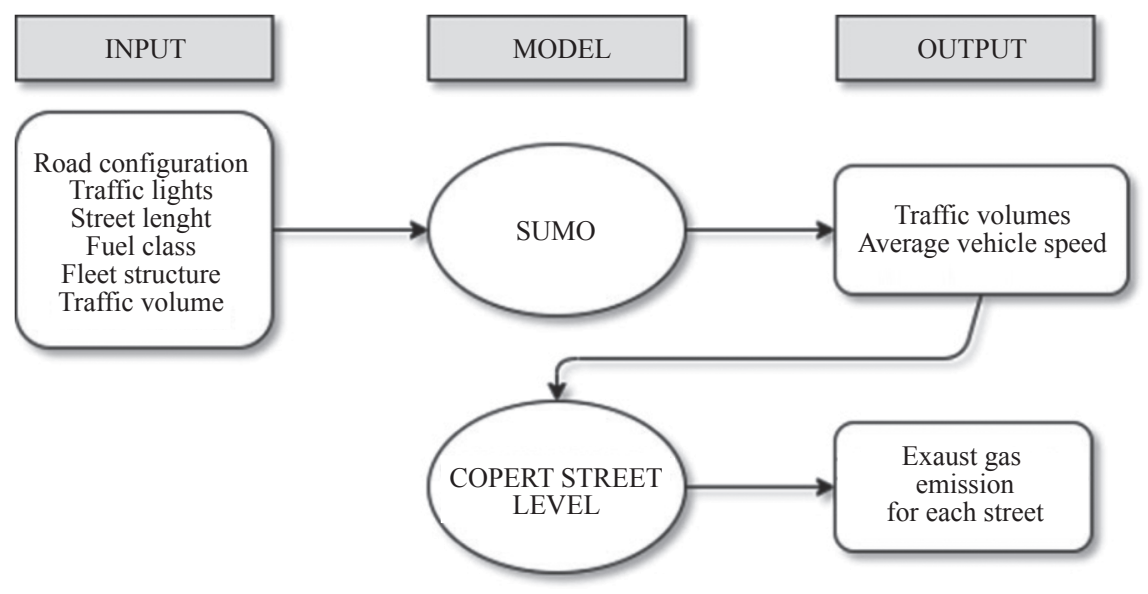

Figure 1-Methodological framework 
and pedestrian crossings, etc. [14, 15]. Therefore, all the mentioned parameters were taken into consideration during the design of the simulation model. The traffic model was created by the Simulation of Urban Mobility (SUMO GUI 1.0.1.). SUMO is an open-source software and a microscopic road traffic simulation software that supports different types of vehicles [16]. This software is space continuous and time discrete. SUMO includes the emission models based on the HBEFA methodology, which means that it provides calculations for all types of vehicles (passenger cars, light-duty vehicles, heavy-duty vehicles, mopeds, and motorcycles) divided into different emission classes according to the fuel classes [17]. The second stage includes the calculation of vehicle emissions on the roads of the city of Rijeka with the highest traffic flow, selected according to the simulation results. So far there have been many different methodologies and methods for calculating the greenhouse emissions in urban transport [18]. One of the most commonly used methodologies for the calculation of vehicle emissions in the European context is COPERT [17]. COPERT is based on special mathematical models that consider vehicle emissions according to vehicle type and technology, and show them as a function of the average vehicle speed [18]. The program is aligned with the 2006 Intergovernmental Panel for Climate Change (IPCC) guidelines for greenhouse emission calculation. It also offers a transparent and standardized way of collecting data used for reporting on greenhouse emissions in accordance with the international conventions and protocols as well as the EU legislation. COPERT was developed by the European Environmental Agency to calculate vehicle emissions for all EU member states. The authors also used the COPERT methodology in this paper, which required the application of the computer software COPERT Street Level v2.4.32. It is a standalone MS Windows software designed for calculating emissions on the road basis (street level pollution modelling).

\subsection{Study area}

According to the last official total population estimate in the Republic of Croatia, conducted in mid-2018, the area of the Republic of Croatia is permanently populated by $4,284,889$ inhabitants, with 296,195 inhabitants living in the Primorje-Gorski Kotar County [21, 22]. Primorje-Gorski Kotar County covers a total area of $3.588 \mathrm{~km}^{2}$, while the
Rijeka city administrative border includes the area of $44 \mathrm{~km}^{2}$ [23]. Rijeka is the largest Croatian port, the third largest city in Croatia, and the administrative center of the Primorje-Gorski Kotar County. Within the administrative borders of the city of Rijeka, there are 121,975 inhabitants, resulting in a population density of 2.772 inhabitants per $\mathrm{km}^{2}$ [24-26]. Hrvatske ceste d.o.o. is responsible for the management of roads crucial for the country and larger cities. The company Rijeka promet d.d. is responsible for the management of over 607 unclassified roads located in the area of the city of Rijeka that enable mutual connection of the numerous city zones [24]. In 2017, there were 2,098,159 vehicles registered in the Republic of Croatia with 161,575 motor vehicles registered in the Primorje-Gorski Kotar County. A total of 95,145 motor vehicles were registered in the Rijeka city area, which makes $58.88 \%$ of the total number of vehicles in the Primorje-Gorski Kotar County [24-26]. The analysis of the data sets about the population in the city of Rijeka and the number of registered vehicles in the area shows that the degree of motorization is 1.29 , i.e., that every inhabitant of the city of Rijeka owns more than one motor vehicle. A detailed analysis of the data about the total number of registered vehicles in the area of the city of Rijeka indicates the share of personal vehicles of $78.23 \%$ with further analysis showing that $40.36 \%$ of these are diesel-powered vehicles and $57.32 \%$ are gasoline-powered vehicles [26]. Furthermore, the structure of the motor vehicle fleet registered in the city of Rijeka is the following: $8.62 \%$ are light-duty vehicles (LDVs), $1.97 \%$ are heavy-duty vehicles (HDVs), and $0.03 \%$ are buses, etc. $[24,26]$.

\subsection{Simulation of the Urban Mobility (SUMO) model setup}

The simulation model of the Rijeka city center is defined by three main simulation stages: the network modelling stage, the demand modelling stage, and the simulation parameters setup stage. The network geometry stage defines a static layer of the traffic model, i.e., the traffic network of the Rijeka city center. The network modelling stage implies the definition of the following objects that describe in detail the traffic network model: roads, lanes per individual road, turning directions for each road, connections between lanes, intersections, and additional road and spatial configurations. Objects of the traffic network are provided by the OpenStreetMap 
(OSM) database which is imported into SUMO by the NETCONVERT tool. By applying the NETEDIT tool, an imported traffic network model was adapted to present more realistic traffic network conditions. Based on the data collected from city authorities, roads and lanes positions were edited, and areas with the desired/reduced speed, pedestrian crossings, traffic lights on intersections, and public transport stops were defined (Figure 2). The generated city of Rijeka traffic network model consists of 647 roads on the city surface of about $44 \mathrm{~km} 2$.

The next stage, demand modelling, implies the arrangement of parameters for the realization of traffic flows on the Rijeka city center traffic network. To carry out this phase, attributes related to vehicle types such as length, width, height, acceleration, deceleration, speed factor, and deviations are defined. In addition to the above mentioned, vehicle dynamic models have been defined: the car following model (behavior of vehicles when approaching and crossing an intersection-Krauss model) and the lane change model (behavior of vehicles when changing the lane due to strategic, cooperative, speed gain or keep right reasons). Determining vehicle routes is the most sensitive part of the demand modelling procedure because it can be carried out by using numerous methods (pros and cons according to the size of the traffic network model area) that require various input data. In SUMO, vehicle routes can be defined by using one of the following procedures: manually, randomly, or by traffic demand generators (assignments) like DUAROUTER， JTCROUTER， JTRROUTER, DFROUTER, MAROUTER, etc. On the traffic lanes of the
Rijeka city center traffic network model, inductive loop traffic detectors are installed which record vehicle volumes and movement directions from source to sink inductive loop detector or in-between detectors. Considering conditions that have to be met to implement the mentioned assignments and the fact that the traffic flows on a defined traffic network are completely known, the DFROUTER assignment was used. The DFROUTER assignment is based on a direct collection of data from induction loop detectors to rebuild/estimate the vehicle volumes and vehicle routes in the domain of the defined traffic network. Every vehicle in the traffic network has its route and moves independently through the network. Accordingly, traffic demand modelling for the defined traffic network of the Rijeka city center can also be conducted by using the JTCROUTER assignment which can generate demand from turncount data transforming the vehicle volumes into flows and turn-ratios which present input data for the JTRROUTER assignment. For the DFROUTER assignment, a list of inductive loop detectors with data including lane ID, inductive loop detectors ID, and their position on the lane is provided. After defining source and sink induction loop detectors, routes for each of the inductive loop detector pairs were computed (O-D pairs). In the next step of implementing the DFROUTER assignment, for each defined O-D pair, volumes of passenger cars and HDVs (with average speed data) according to the real-world detectors were assigned to compute traffic flows on the modelled traffic network. Vehicle volume datasets of one-year real-world detector measures (Tuesday and Thursday) were provided as inputs. Measures

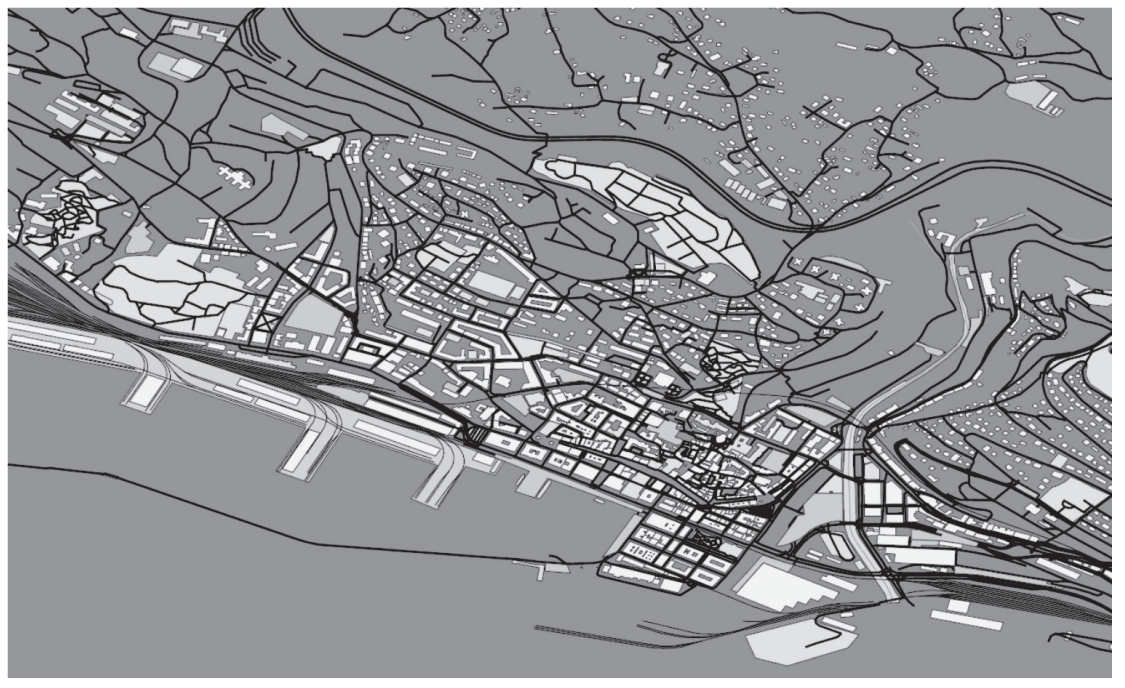

Figure 2 - Rijeka city traffic network 
were aggregated into 12 time intervals (steps) per $900 \mathrm{~s}$ for a defined peak hour traffic period (14:00 17:00). Setup simulation parameters were defined in order to simulate randomized entrances of vehicle flows that are generated according to the DFROUTER assignment from the source inductive loop detectors placed towards the sink inductive loop detector. The duration of simulations was set to a period of 10,800 s (14:00-17:00) where the first and last $900 \mathrm{~s}$ present the heating and cooling time of the simulation model traffic network. After simulating the model for 15 times with different randomized vehicle entrances for network roads (edges), the following average aggregated data based on simulation time periods (steps) were collected: number of vehicles, travel times, vehicle delays, and queue lengths. According to the analyzed results of the output parameters, critical values were defined for every road. Traffic network sections, i.e., roads with critical values of the defined output parameters were selected (Figure 3), based on which the application of the COPERT methodology for determining the impacts of the traffic flows realization on vehicle emissions generated in the Rijeka city center traffic network will be conducted.

The selected roads with the highest traffic volumes are shown in Figure 3: R6, R38, R40-41, R4647, R24-25, and R20-21. The mentioned roads are isolated from the network model because they primarily represent basic origin-destination points that accept most origin-destination patterns of vehicle travels of the Rijeka city center. The result of isolating these roads is also that their origin-destination points represent traffic intersections; with the remaining intersections located on their route, this affects numerous interruptions in the vehicle traffic flow realization and causes additional vehicle stops and delays, which further affect higher vehicle emissions. The selected roads represent the basis for the application of the COPERT methodology, which will be used to determine the impact of the traffic flow realization on vehicle emissions generated in the Rijeka city center traffic network.

\subsection{COPERT Street Level model setup}

The application of the computer software COPERT Street Level assumes the determination of three interconnected sets of input data based on the results of peak hour simulation of the city of Rijeka traffic network. The first input data set refers to vehicle volume data, vehicle speed, road length, and initial and final road location coordinates, i.e., on the data that define the initial state of traffic flows on the selected roads of the simulation model. The second input data set required for the application of the COPERT Street Level refers to the recorded vehicle fleet structure data (vehicle compositions) on a particular selected road of the model. The third set of input data is based on the fuel type structure data of the individual vehicle categories and applied fuel standards for each of the defined fuel types. The first set of input data, which is the basis for quantification and analysis of the negative impact of vehicle emissions on the environment, is shown in Table 1.

Table 1 shows the input data of six selected roads in Rijeka, singled out from the city road network as roads with the highest traffic volumes based on the defined criteria of the number of motor vehicles in

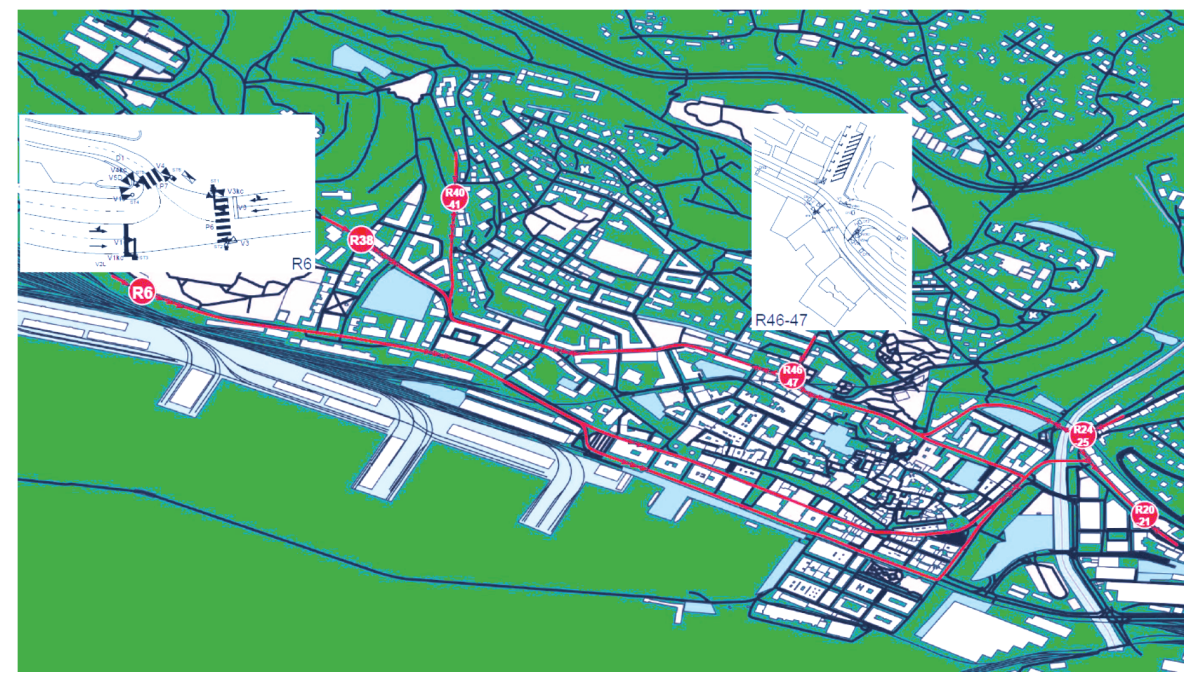

Figure 3 -Selected roads with the highest traffic volume in the city of Rijeka 
Maglić L, Krljan T, Grubišić N, Maglić L. Estimating Urban Road Transport Vehicles Emissions in the Rijeka City Streets

Table 1 - COPERT Street Level input data

\begin{tabular}{|c|c|c|c|c|c|c|c|c|c||}
\hline \multirow{2}{*}{ Road_ID } & \multirow{2}{*}{$\begin{array}{c}\text { Veh__Vol. } \\
2017\end{array}$} & \multirow{2}{*}{$\begin{array}{c}\text { Road_Length } \\
{[\mathrm{km}]}\end{array}$} & \multicolumn{3}{|c|}{ SPEED $[\mathrm{km} / \mathrm{h}]$} & \multirow{2}{*}{$\begin{array}{c}\text { start_ } \\
\text { lat_x }\end{array}$} & $\begin{array}{c}\text { start_ } \\
\text { long_y }\end{array}$ & $\begin{array}{c}\text { end_- } \\
\text { lat_x }\end{array}$ & $\begin{array}{c}\text { end_ } \\
\text { long_y }\end{array}$ \\
\hline \hline R6 & 365.00 & 1.30 & 25.00 & 33.50 & 42.00 & 45.328172 & 14.436987 & 45.333759 & 14.422600 \\
\hline R38 & 384.00 & 2.20 & 18.00 & 28.50 & 39.00 & 45.333505 & 14.429943 & 45.346557 & 14.410583 \\
\hline R40-41 & 235.00 & 0.65 & 17.00 & 26.00 & 35.00 & 45.331476 & 14.433216 & 45.337110 & 14.432793 \\
\hline R46-47 & 102.00 & 0.60 & 15.00 & 23.00 & 31.00 & 45.329551 & 14.443380 & 45.333369 & 14.438159 \\
\hline R24-25 & 171.00 & 0.80 & 23.00 & 37.50 & 52.00 & 45.327864 & 14.448903 & 45.333743 & 14.453507 \\
\hline R20-21 & 818.00 & 0.50 & 16.00 & 27.50 & 39.00 & 45.326481 & 14.449813 & 45.324530 & 14.454183 \\
\hline \hline
\end{tabular}

the peak hour time interval (one hour of observation). Data analysis clearly shows that the average length of roads in the selected research area is 1.008 $\mathrm{km}$, where it is important to notice that the greatest length of the road is $2.20 \mathrm{~km}(\operatorname{road} \mathrm{R} 38)$ and the smallest length is $0.50 \mathrm{~km}$ (road R20-21). The average number of vehicles recorded during the input data collection is 345.83 vehicles. The data about vehicle speed, based on the minimum (V_min.), average (V_aver.), and maximum (V_max.) speed, were obtained by measurement on specific sections of the selected roads. In the research area, it is important to single out the data referring to the road R20-21, which is the most important road for connecting the narrow central part of the city with numerous residential areas situated on the marginal eastern part of the city. Road R20-21, with a length of $0.50 \mathrm{~km}$, has the greatest number of motor vehicles, 818 vehicles, in the interval of observation, moving at the average speed of $27.50 \mathrm{~km} / \mathrm{h}$. The largest amount of motor vehicles on the mentioned road is attributed to the fact that the inhabitants of the city residential areas prefer to use precisely the R20-21 road as it does not have many traffic lights or pedestrian crossings that cause frequent stops, thus reducing the capacity of the road and increasing the total time of travel to the final destination. A great difference was also noted in the number of motor vehicles on the road R20-21 compared to the other selected roads owing to adequately planned and designed public transportation lay-bys, which avoid the possibility of stopping the traffic flow for taking on or discharging passengers on public transportation stops. Besides road R20-21, owing to the specific features of the research area, it is also important to single out the road R46-47, distinguished according to Table 1 with the least number of motor vehicles, 102 vehicles, in the observed interval, running at the average speed of $23.00 \mathrm{~km} / \mathrm{h}$ on the section of $0.60 \mathrm{~km}$ of the road. For the interpretation of the input data, it is also important to analyze the relation of the data describing the traffic flow of the road R46-47 with the input data describing the traffic flow of the road R20-21. Road R46-47 has 647 fewer motor vehicles than road R20-21. Such disproportion between the numbers of vehicles should be analyzed first because the length and the average vehicle speed on the road R46-47 are only $0.1 \mathrm{~km}$ and $4.5 \mathrm{~km} / \mathrm{h}$ lower than on the road R20-21, respectively. The result of such input data can be attributed to the fact that the road R46-47 is situated in the narrow city center, where the issue of vehicle parking is handled quite inadequately owing to the lack of space. Due to that, there are numerous illegally stopped and parked vehicles, which obstructs the realization of active traffic flow and increases all parameters relevant for determining the capacity of the road. Moreover, as a consequence of such discrepancy of input data on the number of vehicles, it is important to mention a large number of pedestrian crossings and bus stops at inadequately created lay-bys, thus increasing the number of stops, and consequently the time of travel, i.e., vehicle delay in the traffic network. Besides the analyzed input data, Table 1 also contains data about the positions of the selected roads defined by the initial and final coordinates on the $\mathrm{X}$ (start lat $\mathrm{x}$; end lat $\mathrm{x}$ ) and $\mathrm{Y}$ (start long $\mathrm{y}$; end long $\mathrm{y}$ ) axes, which serve as the basis for making a cartographic presentation of the location of each road (Coordinate system WGS1984).

The second set of input data refers to data on the represented motor vehicle composition structure on selected roads. Vehicle composition structure data was obtained according to the measurements carried out through road detectors installed on specific cross-sections of the simulation model, 
Maglić L, Krljan T, Grubišić N, Maglić L. Estimating Urban Road Transport Vehicles Emissions in the Rijeka City Streets

Table 2 - The structure of motor vehicles on selected roads

\begin{tabular}{||c|c|c|c|c|c|c||}
\hline Road_ID & PC/\%PC & LDV/\%LDV & HDV/\%HDV & Buses/\%Buses & $\begin{array}{c}\text { Mopeds/ } \\
\% \text { Mopeds }\end{array}$ & $\begin{array}{c}\text { Motorcycles/ } \\
\text { \%Motorcycles }\end{array}$ \\
\hline \hline R6 & $269.60 / 73.86$ & $11.37 / 3.12$ & $11.97 / 3.28$ & $44.04 / 12.07$ & $16.69 / 4.57$ & $11.32 / 3.10$ \\
\hline R38 & $307.68 / 80.13$ & $13.60 / 3.36$ & $13.60 / 3.54$ & $17.98 / 4.68$ & $18.96 / 4.94$ & $12.86 / 3.35$ \\
\hline R40-41 & $189.97 / 80.84$ & $8.40 / 3.40$ & $8.40 / 3.57$ & $9.00 / 3.83$ & $11.71 / 4.98$ & $7.94 / 3.38$ \\
\hline R46-47 & $80.64 / 79.06$ & $3.58 / 3.34$ & $3.58 / 3.51$ & $6.00 / 5.88$ & $4.99 / 4.89$ & $3.39 / 3.32$ \\
\hline R24-25 & $138.61 / 81.06$ & $6.15 / 3.42$ & $6.15 / 3.60$ & $5.99 / 3.51$ & $8.58 / 5.02$ & $5.82 / 3.40$ \\
\hline R20-21 & $667.11 / 81.55$ & $28.10 / 3.44$ & $29.58 / 3.62$ & $24.00 / 2.93$ & $41.24 / 5.04$ & $27.97 / 3.42$ \\
\hline \hline
\end{tabular}

and validated in accordance with the collected and analyzed data carried out by the traffic management service "Rijeka promet". This research on the evaluation of the impact of vehicle emissions includes six categories of motor vehicles which represent the greatest shares in the traffic flow on the selected roads (Table 2).

Table 2 shows the share of certain motor vehicle categories concerning the total number of vehicles running on the selected roads. The collected data about the traffic flows on the selected roads included in Table 3 refer to the following categories of motor vehicles: passenger cars (PC), light-duty vehicles (LDV), heavy-duty vehicles (HDV), buses, mopeds, and motorcycles. Passenger cars have a dominant share of $79.42 \%$ on average on each of the selected roads, while the average shares of other motor vehicle categories on the selected roads are the following: $3.34 \%, 3.52 \%, 5.48 \%, 4.91 \%$, and $3.33 \%$ respectively. Considering the average share of buses in traffic flows of the selected roads, it is important to mention the share of buses of $12.07 \%$ in the total traffic flow of the R6 road. Such an uneven share of buses in the total traffic flow in relation to other roads occurs because road R6 is the primary road connecting the extreme points of the city center, having numerous destination centers of various activities for the population in its vicinity. It is also important to mention the share of buses in the traffic flow of the road R46$47,5.88 \%$, whereby the analysis of the input data from Table 1 shows the obstruction of the traffic flow by buses due to inadequately designed lay-bys. According to Table 2, the use of busses (public transport) in the city of Rijeka is low, so it is necessary to implement measures to encourage the use of public transport services. The measures are described through conditions that the public transport must fulfill: on-demand transport located in prime areas; friendly, efficient, comfortable and cheap service; electronic

timetable boards that notify people about delays and travel times; easy-to-read transportation maps and timetables, etc. All public transport services should be interconnected, with frequent service and sufficient capacities.

As part of the project implemented under the operational program "Competitiveness and Cohesion 2014-2020", within the Priority Axis 7 "Connectivity and Mobility", Investment Priority 7ii Development and Improvement of Environmentally Friendly Transport Systems, the city of Rijeka already bought 22 new busses, implemented displays that announce bus arrivals/departures at bus stops, and smart traffic lights at 6 signalized intersections, but also developed a mobile and web application that tracks live bus positions and bus arrivals at bus stops. In the period 2020-2030, it is reasonable to expect that the city council and government will implement more measures that will additionally promote and improve the current situation of all public transport services in the city of Rijeka.

In order to more credibly and more thoroughly quantify and implement the impact analysis of vehicle emissions generated by an individual category of motor vehicles, the third set of data is also defined as necessary for modelling by using the COPERT Street Level computer software, which includes data on the shares of the types of propulsion fuels applied to each category of motor vehicles operating on the selected roads. The data recorded in the initial year 2017 are collected according to the analysis conducted by the "Vehicle Center of Croatia - CVH" and presented within Table 3.

The data presented in Table 3 show the shares of motor vehicle categories in the traffic flows of the selected roads concerning the types of propulsion fuels recorded in the initial year. The fuel types used in the selected vehicle categories and defined in the research are the following: leaded 
Maglić L, Krljan T, Grubišić N, Maglić L. Estimating Urban Road Transport Vehicles Emissions in the Rijeka City Streets

Table 3 - Vehicle category and fuel types on selected roads in 2017 (values expressed in a number of vehicles)

\begin{tabular}{|c|c|c|c|c|c|c|c|}
\hline Vehicle category & Leaded gasoline & $\begin{array}{l}\text { Unleaded } \\
\text { gasoline }\end{array}$ & Diesel & LPG & $\begin{array}{l}\text { Hybrid } \\
\text { gasoline }\end{array}$ & $\mathrm{CNG}$ & Bio-ethanol \\
\hline \multicolumn{8}{|c|}{ R6 } \\
\hline $\mathrm{PC}$ & 0.08 & 154.46 & 108.81 & 1.62 & 4.64 & 1 & 1 \\
\hline LDV & 1 & 0.34 & 11.04 & 1 & 1 & 1 & 1 \\
\hline HDV & 0.06 & 1 & 11.91 & 1 & 1 & 1 & 1 \\
\hline Buses & 43.76 & l & l & l & l & 0.28 & / \\
\hline Mopeds & 16.69 & l & l & l & l & l & 1 \\
\hline Motorcycles & 11.32 & l & l & / & / & l & l \\
\hline \multicolumn{8}{|c|}{ R38 } \\
\hline $\mathrm{PC}$ & 0.09 & 176.27 & 124.18 & 1.85 & 5.29 & 1 & 1 \\
\hline LDV & / & 0.38 & 12.53 & 1 & I & 1 & 1 \\
\hline HDV & 0.06 & 1 & 13.53 & 1 & l & 1 & 1 \\
\hline Buses & 17.87 & 1 & 1 & 1 & 1 & 0.12 & l \\
\hline Mopeds & 18.96 & 1 & 1 & 1 & 1 & 1 & 1 \\
\hline Motorcycles & 12.86 & l & l & I & 1 & 1 & 1 \\
\hline \multicolumn{8}{|c|}{ R40-41 } \\
\hline $\mathrm{PC}$ & 0.06 & 108.83 & 76.67 & 1.14 & 3.27 & 1 & 1 \\
\hline LDV & 1 & 0.24 & 7.74 & 1 & 1 & 1 & 1 \\
\hline HDV & 0.04 & 1 & 8.36 & 1 & I & I & 1 \\
\hline Buses & 8.94 & 1 & l & 1 & 1 & 0.06 & 1 \\
\hline Mopeds & 11.71 & 1 & 1 & 1 & 1 & 1 & 1 \\
\hline Motorcycles & 7.94 & l & l & / & l & l & l \\
\hline \multicolumn{8}{|c|}{ R46-47 } \\
\hline $\mathrm{PC}$ & 0.02 & 46.20 & 32.55 & 0.48 & 1.39 & 1 & 1 \\
\hline LDV & 1 & 0.10 & 3.30 & 1 & 1 & 1 & 1 \\
\hline HDV & 0.02 & 1 & 3.56 & 1 & 1 & 1 & 1 \\
\hline Buses & 5.96 & l & l & l & l & 0.04 & l \\
\hline Mopeds & 4.99 & 1 & 1 & 1 & 1 & 1 & 1 \\
\hline Motorcycles & 3.39 & 1 & 1 & 1 & 1 & 1 & 1 \\
\hline \multicolumn{8}{|c|}{ R24-25 } \\
\hline $\mathrm{PC}$ & 0.04 & 79.41 & 55.94 & 0.83 & 2.38 & 1 & 1 \\
\hline LDV & 1 & 0.17 & 5.67 & 1 & 1 & 1 & 1 \\
\hline HDV & 0.03 & 1 & 6.13 & 1 & 1 & 1 & 1 \\
\hline Buses & 5.96 & 1 & 1 & 1 & 1 & 0.04 & 1 \\
\hline Mopeds & 8.58 & 1 & 1 & 1 & 1 & 1 & 1 \\
\hline Motorcycles & 5.82 & 1 & 1 & 1 & 1 & 1 & 1 \\
\hline \multicolumn{8}{|c|}{ R20-21 } \\
\hline $\mathrm{PC}$ & 0.20 & 382.19 & 269.25 & 4.00 & 11.47 & 1 & 1 \\
\hline LDV & 1 & 0.83 & 27.26 & 1 & 1 & 1 & 1 \\
\hline HDV & 0.14 & 1 & 29.44 & 1 & 1 & 1 & 1 \\
\hline Buses & 23.85 & 1 & 1 & 1 & 1 & 0.15 & 1 \\
\hline Mopeds & 41.24 & 1 & 1 & 1 & 1 & 1 & 1 \\
\hline Motorcycles & 27.97 & I & l & I & l & l & l \\
\hline
\end{tabular}


gasoline, unleaded gasoline, diesel, LPG, hybrid gasoline, $\mathrm{CNG}$, and bioethanol. In the total traffic flow structure of the selected roads during peak hours an average value of $13.42 \%$ of the vehicles that use leaded gasoline fuel, $45.76 \%$ that use unleaded gasoline fuel, and $38.93 \%$ that use diesel fuel was recorded, while the remaining share of the traffic volume structure includes vehicles that generate propulsion by using LPG, hybrid gasoline, $\mathrm{CNG}$ and bioethanol fuels. Vehicles from the PC category, which according to Table 3 represent the largest share of the traffic volume on the selected roads, mostly use unleaded gasoline and diesel fuels. The average share values of the PC vehicle category applying the specified fuels on the selected roads are $57.29 \%$ (unleaded gasoline) and $40.36 \%$ respectively, while the shares of the number of vehicles that apply leaded gasoline, LPG and hybrid fuels are unrepresentative for conducting further analysis due to low values. It is also important to notice that the highest number of the total number of PC vehicles on the selected roads in the peak hour time interval is using unleaded gasoline and diesel fuels recorded on the road R6 and R20-21, which is $12.69 \%$ and $31.39 \%$, respectively. When it comes to LDVs and HDVs that operate on the selected roads, $97.03 \%$ and $99.53 \%$ of them, respectively, use diesel fuel, while the remaining share of the LDVs and HDVs use unleaded gasoline fuel, i.e., leaded gasoline fuel. It is also important to point out that $99.36 \%$ of buses on the selected roads use leaded gasoline propellant, while the remaining share uses the $\mathrm{CNG}$ propellant. The last category of motor vehicles recorded in the traffic flow structure during peak hours - mopeds and motorcycles - use unleaded gasoline fuel exclusively $(100 \%)$.

\subsection{Scenario Management Setup}

Except for the initial year 2017, the quantification and analysis of the impact of vehicle emissions generated by certain categories of motor vehicles represented within the traffic flow on the selected roads were also carried out for the characteristic future five-year period from 2020 to 2030 . The procedure used for determining the results for the defined periods, besides obtaining precise results, provides insight into the changes in the values, which may lead to specific conclusions about the changes in certain kinds of vehicle emissions. Data on the structures of the applied fuels depending on the motor vehicle categories are defined and collected for the period 2020-2030 by the COPERT Street Level computer software (Table 4). These data are defined at the level of the Republic of Croatia, and they can also be applied when quantifying and conducting further analysis of vehicle emissions at the level of the city of Rijeka due to the assumption of minimum deviations caused by unchanged trends in the application of motor vehicles using the defined types of fuel.

Table 4 - Vehicle categories by fuel types - time period from 2017 to 2030 (values expressed in \%)

\begin{tabular}{|c|c|c|c|c|c|c|c|c|}
\hline Vehicle category & Year & Leaded gasoline & $\begin{array}{l}\text { Unleaded } \\
\text { gasoline }\end{array}$ & Diesel & LPG & $\begin{array}{l}\text { Hybrid } \\
\text { gasoline }\end{array}$ & $\mathrm{CNG}$ & $\begin{array}{c}\text { Bio- } \\
\text { ethanol }\end{array}$ \\
\hline \multirow{3}{*}{ Passenger cars } & 2020 & 1 & 51.66 & 44.20 & 0.47 & 3.67 & 1 & 1 \\
\hline & 2025 & I & 42.02 & 49.44 & 0.10 & 8.44 & 1 & 1 \\
\hline & 2030 & I & 35.45 & 51.65 & 0.04 & 12.86 & 1 & 1 \\
\hline \multirow{3}{*}{ LDV } & 2020 & I & 1.96 & 98.04 & l & l & l & I \\
\hline & 2025 & l & 1.15 & 98.85 & l & l & I & l \\
\hline & 2030 & I & 0.97 & 99.03 & I & 1 & 1 & 1 \\
\hline \multirow{3}{*}{ HDV } & 2020 & 1 & 1 & 99.53 & 1 & 1 & 1 & 1 \\
\hline & 2025 & 1 & 1 & 99.53 & 1 & 1 & 1 & 1 \\
\hline & 2030 & 0.47 & 1 & 99.53 & 1 & 1 & 1 & 1 \\
\hline \multirow{3}{*}{ Buses } & 2020 & 99.37 & 1 & 1 & 1 & 1 & 0.63 & 1 \\
\hline & 2025 & 99.38 & 1 & 1 & 1 & 1 & 0.62 & 1 \\
\hline & 2030 & 0.47 & 1 & 1 & 1 & 1 & 0.63 & 1 \\
\hline Mopeds & $2020-2030$ & 0.47 & 1 & 1 & 1 & 1 & 1 & 1 \\
\hline Motorcycles & $2020-2030$ & 100.00 & 1 & 1 & 1 & 1 & 1 & 1 \\
\hline
\end{tabular}


In data interpretation, particular attention should be paid to the category of PCs due to its significant share in the total structure, shown in Table 2. In the base year 2017 (Table 3), the majority of PCs used unleaded gasoline and diesel fuel, indicated by the share of $57.29 \%$ and $40.36 \%$, respectively. By observing the relation of the PC share value in 2030 , considering the values recorded in 2017 , the following can be concluded: the share of PCs using unleaded gasoline fuel will be lower by $21.84 \%$ with the average reduction of unleaded gasoline fuel share in PCs of $7.28 \%$ for each subsequent observed period. The use of diesel fuel in PCs will increase by $11.29 \%$, whereby the average increase in the use of diesel fuel in PCs will be $3.76 \%$ for each of the subsequent observed period. The use of hybrid gasoline fuel in PCs in 2030 will be higher by $11.14 \%$ in relation to 2017 , which represents an average increase in the use of hybrid gasoline fuel of $3.71 \%$ for each subsequent observed period. More significant shares, as well as the changes in the use of other fuel types in the category of PCs, were not recorded, therefore their interpretation is not statistically significant. The appearance of a negative growth trend in the use of diesel-fueled PCs may be attributed to the increase in the degree of motorization and the overcapacity of the PC market with the diesel-fueled PCs in Croatia. This negative trend may be caused by the import of diesel-fueled PCs from central and western European countries as a result of EU initiatives to reduce the usage of diesel-fueled PCs. Furthermore, the negative trend may be attributed to the lower prices of the diesel fuel and smaller average consumption of fuel in such PCs. The structure of the change in the share of the fuel type used should be analyzed and interpreted for the LDV category. According to the data shown in Table 3 (the initial year 2017), the LDVs used leaded gasoline, unleaded gasoline, and diesel fuels. The shares and changes in the shares of the mentioned fuel types in this vehicle category in the observed periods are the following: the share of LDVs using unleaded gasoline was $2.96 \%$ in 2017 with the decreasing trend of value in the amount of $1.99 \%$ for 2030 ; the share of LDVs using diesel fuel was $97.03 \%$ in 2017 with an increase of $2 \%$ in 2030. As there were no significant differences in the shares and the changes in the use of other fuel types in the remaining vehicle categories, they were not further analyzed. The variable data that significantly affect the overall result in the quantification of harmful vehicle gasses and the implementation of further analysis refer to the number of vehicles in the defined characteristic five-year periods.

The research and assessment of the number of vehicles in the defined peak hours for the selected roads were carried out by the traffic management service "Rijeka Promet" (Table 5). The research was based on a five-year analysis of the traffic flow data. It is also important to emphasize the fact that the changes in the structure of vehicle compositions are a very important parameter in further assessments. However, if changes, i.e., deviations from the initial data are minimal and there are no significant impacts on the final results, existing vehicle compositions recorded on the selected roads in the initial year 2017 may be taken into account (Table 2) for the quantification of vehicle emissions in the period 2020-2030.

The data shown in Table 5 refer to the assumed values of the number of vehicles on the selected roads for the periods from 2017 to 2030 . The vehicle number for each of the observed periods is constantly dropping by $3.84 \%$ on average, considering the number of vehicles in the period 2020/2017, and by $6.23 \%$ considering the number of vehicles in the periods $2025 / 2020$ and $2030 / 2025$. It is also important to note the following decrease in the

Table 5 - Traffic volumes on the selected roads - defined time periods (in number of vehicles)

\begin{tabular}{||c|c|c|c|c|c|c||}
\cline { 2 - 8 } \multicolumn{1}{c|}{} & $\mathrm{R} 6$ & $\mathrm{R} 38$ & $\mathrm{R} 40-41$ & $\mathrm{R} 46-47$ & $\mathrm{R} 24-25$ & $\mathrm{R} 20-21$ \\
\hline \hline 2017 & 365.21 & 383.65 & 234.65 & 101.00 & 155.00 & 818.35 \\
\hline $2020 / 2017$ (in \%) & -7.83 & -4.00 & -0.42 & -0.99 & -9.38 & -0.39 \\
\hline 2020 & 336.62 & 368.32 & 233.66 & 100.00 & 140.46 & 815.17 \\
\hline $2025 / 2020$ (in \%) & -12.70 & -6.57 & -0.70 & -1.64 & -15.14 & -0.65 \\
\hline 2025 & 293.87 & 344.12 & 232.03 & 98.36 & 119.19 & 809.88 \\
\hline $2030 / 2025$ (in \%) & -12.70 & -6.57 & -0.70 & -1.64 & -15.14 & -0.65 \\
\hline 2030 & 256.55 & 321.51 & 230.41 & 96.75 & 101.15 & 804.63 \\
\hline
\end{tabular}


number of vehicles on the selected roads, considering the relation to the values recorded for 2030 and 2017: $29.75 \%, 16.20 \%, 1.81 \%, 4.21 \%, 34.74 \%$, and $1.68 \%$, respectively. A considerable decrease in vehicle number was recorded for the roads R6 and R24-25, both located in the narrow city center. In the calculation of vehicle emissions, caused by motor vehicles on certain roads in Rijeka, the following categories of vehicle emissions were taken into consideration: $\mathrm{CO}, \mathrm{CO}_{2}, \mathrm{NO}_{\mathrm{x}}$ and $\mathrm{PM}$. The results obtained based on the variation of input data characteristics for each defined period were described in detail and analyzed in the following chapter.

\section{RESULTS AND DISCUSSION}

The analysis includes the results based on the COPERT methodology and refers to the vehicle emissions of $\mathrm{CO}, \mathrm{CO}_{2}, \mathrm{NO}_{\mathrm{x}}$, and $\mathrm{PM}$ on the six selected roads in Rijeka for the period from 2017 to 2030. Relevant statistical data, collected from the competent services for traffic management in the Rijeka city area, were used for the calculation of vehicle emissions in 2017. Therefore, the mentioned year is considered as the reference year. For the evaluation of the mentioned vehicle emissions in 2020, 2025, and 2030, the authors adapted the model according to the IPCC and EMISIA guidelines. The report itself contains several pages, so this part of the paper emphasizes only the most relevant elements of the report, shown in Table 6 .

The data in Table 6 clearly show that the road R38 has the longest road section of $2.2 \mathrm{~km}$, while the shortest one is R20-21 with a total length of $0.5 \mathrm{~km}$. In the road traffic emission calculation, the program COPERT Street Level takes into consideration the length of the road section (Table 1), total number of vehicles (Table 1), traffic flow structure (Table 2), and applied types of propulsion fuels regarding each of the motor vehicle categories (Table 3). On the basis of that, road R20-21 was singled out as the most

Table 6-Calculated vehicle emissions for a defined time period (in $\mathrm{kg} / \mathrm{km}$ per hour)

\begin{tabular}{|c|c|c|c|c|c|c|}
\hline Road ID & Road length $[\mathrm{km}]$ & Year & $\mathrm{CO}[\mathrm{kg} / \mathrm{km}]$ & $\mathrm{CO}_{2}[\mathrm{~kg} / \mathrm{km}]$ & $\mathrm{NO}_{x}[\mathrm{~kg} / \mathrm{km}]$ & $\mathrm{PM}[\mathrm{kg} / \mathrm{km}]$ \\
\hline \multirow{4}{*}{ R6 } & \multirow{4}{*}{1.3} & 2017 & 0.226852499 & 103.1893920 & 0.151940426 & 0.002955811 \\
\hline & & 2020 & 0.177027171 & 94.71888562 & 0.079526133 & 0.001763807 \\
\hline & & 2025 & 0.124055191 & 81.55335069 & 0.047041826 & 0.001180433 \\
\hline & & 2030 & 0.081084430 & 70.47441672 & 0.037716043 & 0.000868013 \\
\hline \multirow{4}{*}{$\mathrm{R} 38$} & \multirow{4}{*}{2.2} & 2017 & 0.249218037 & 92.71893409 & 0.115420102 & 0.002478651 \\
\hline & & 2020 & 0.205448779 & 88.06917330 & 0.067264426 & 0.001718016 \\
\hline & & 2025 & 0.154345235 & 80.71179848 & 0.045873610 & 0.001324341 \\
\hline & & 2030 & 0.106028018 & 74.25118046 & 0.040390370 & 0.001045708 \\
\hline \multirow{4}{*}{ R40-41 } & \multirow{4}{*}{0.65} & 2017 & 0.156484567 & 56.95723267 & 0.068900585 & 0.001495321 \\
\hline & & 2020 & 0.134130054 & 56.17101815 & 0.042223549 & 0.001092869 \\
\hline & & 2025 & 0.106741613 & 54.51199072 & 0.030907754 & 0.000902231 \\
\hline & & 2030 & 0.077379516 & 53.03923927 & 0.028931215 & 0.000756494 \\
\hline \multirow{4}{*}{ R46-47 } & \multirow{4}{*}{0.6} & 2017 & 0.072079181 & 28.31575585 & 0.037534756 & 0.000757845 \\
\hline & & 2020 & 0.060152797 & 27.49881765 & 0.021929735 & 0.000517117 \\
\hline & & 2025 & 0.047115405 & 26.40167060 & 0.015383862 & 0.000410644 \\
\hline & & 2030 & 0.034200905 & 25.67076491 & 0.014227709 & 0.000345909 \\
\hline \multirow{4}{*}{ R24-25 } & \multirow{4}{*}{0.8} & 2017 & 0.102243839 & 34.87983865 & 0.040646487 & 0.000947649 \\
\hline & & 2020 & 0.072930699 & 28.33856154 & 0.020833759 & 0.000585236 \\
\hline & & 2025 & 0.050164354 & 23.66513046 & 0.013260481 & 0.000416739 \\
\hline & & 2030 & 0.031288519 & 19.77157999 & 0.010675635 & 0.000294514 \\
\hline \multirow{4}{*}{ R20-21 } & \multirow{4}{*}{0.5} & 2017 & 0.536524842 & 188.1429180 & 0.218327692 & 0.004901555 \\
\hline & & 2020 & 0.462176229 & 185.6247021 & 0.136208866 & 0.003671695 \\
\hline & & 2025 & 0.369234260 & 180.4858122 & 0.101549800 & 0.003074693 \\
\hline & & 2030 & 0.267874291 & 175.9525452 & 0.095776404 & 0.002578266 \\
\hline
\end{tabular}


polluted road among the selected roads in the city of Rijeka. In 2017, on the R20-21 road section, there were 818 vehicles recorded within one hour (Table 1) with the share of PCs of about $81 \%$ (Table 2), releasing $0.536524842 \mathrm{~kg} / \mathrm{km}$ of $\mathrm{CO}, 188.142918$ $\mathrm{kg} / \mathrm{km}$ of $\mathrm{CO}_{2}, 0.218327692 \mathrm{~kg} / \mathrm{km}$ of $\mathrm{NO}_{\mathrm{x}}$ and $0.004901555 \mathrm{~kg} / \mathrm{km}$ of PM per hour. Figure 4, made on the basis of Table 6, provides a clear illustration of the results.

Figure 4 shows that all released vehicle emissions would be reduced on the selected roads in the city of Rijeka in the period from 2017 to 2030. In the period from 2017 to 2030 , the $\mathrm{CO}$ emission on the observed roads would be reduced on average by $57 \%, \mathrm{CO}_{2}$ by $20 \%$, PM by $58 \%$, while the greatest reduction of $65 \%$ would occur for $\mathrm{NO}_{\mathrm{x}}$ emission. The road R20-21, defined as the road generating the greatest share of vehicle emissions according to the research results, would record a reduction of $\mathrm{CO}$ emission by $50.07 \%$ in 2030 in relation to 2017 , representing an average decrease in value by $5.20 \%$ for each year. The emission of $\mathrm{CO}_{2}$ on the aforementioned road would be lower by $6.47 \%$ in 2030 in relation to the reference year
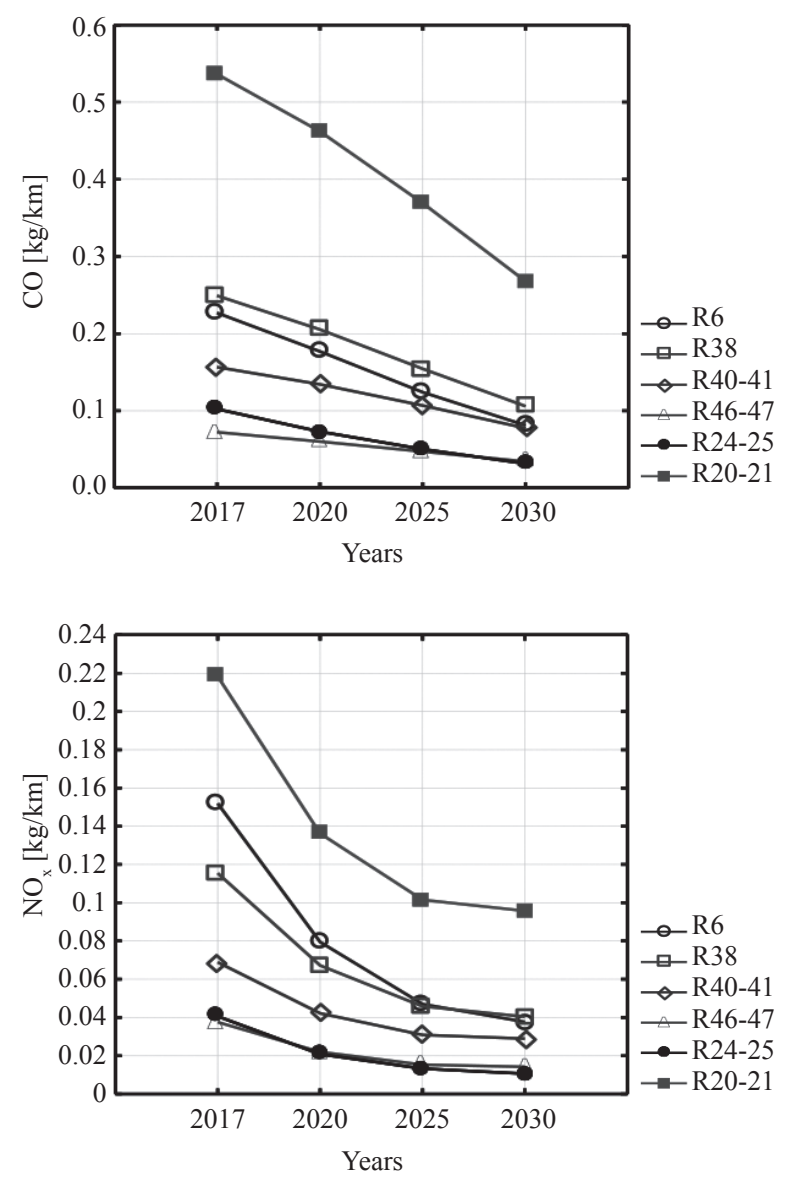

2017, which is an annual reduction in the value of emission by $0.51 \%$ on average. Research results show a progressive decrease in the $\mathrm{NO}_{\mathrm{x}}$ emissions, whereby its value would decrease by $56.13 \%$ in 2030 in relation to the reference year 2017. Such a drastic reduction of $\mathrm{NO}_{\mathrm{x}}$ is the result of an average annual decrease rate of $6.14 \%$ for each future oneyear period. Also, the last observed emission of PM records a decrease in 2030 by $52.65 \%$ in relation to 2017, which represents an average annual decrease of $4.81 \%$. However, on the other hand, according to research results, road R46-47 represents an extreme that should be separately analyzed. Owing to the lower traffic flow, but also environmentally more acceptable standards, road R46-47 in relation to the analyzed road R20-21 records considerably smaller emissions in each observed period. So, in 2030, road R46-47 records a lower CO emission by $52.55 \%$ compared to the reference year 2017 , which is the result of an annual decrease rate of about $5.57 \%$. In 2030, $\mathrm{CO}_{2}$ emission would be lower by $9.34 \%$ in relation to 2017 , with an annual decrease rate of $0.75 \%$. Furthermore, it is also important to note that in 2030 the values of $\mathrm{NO}_{\mathrm{x}}$ record a
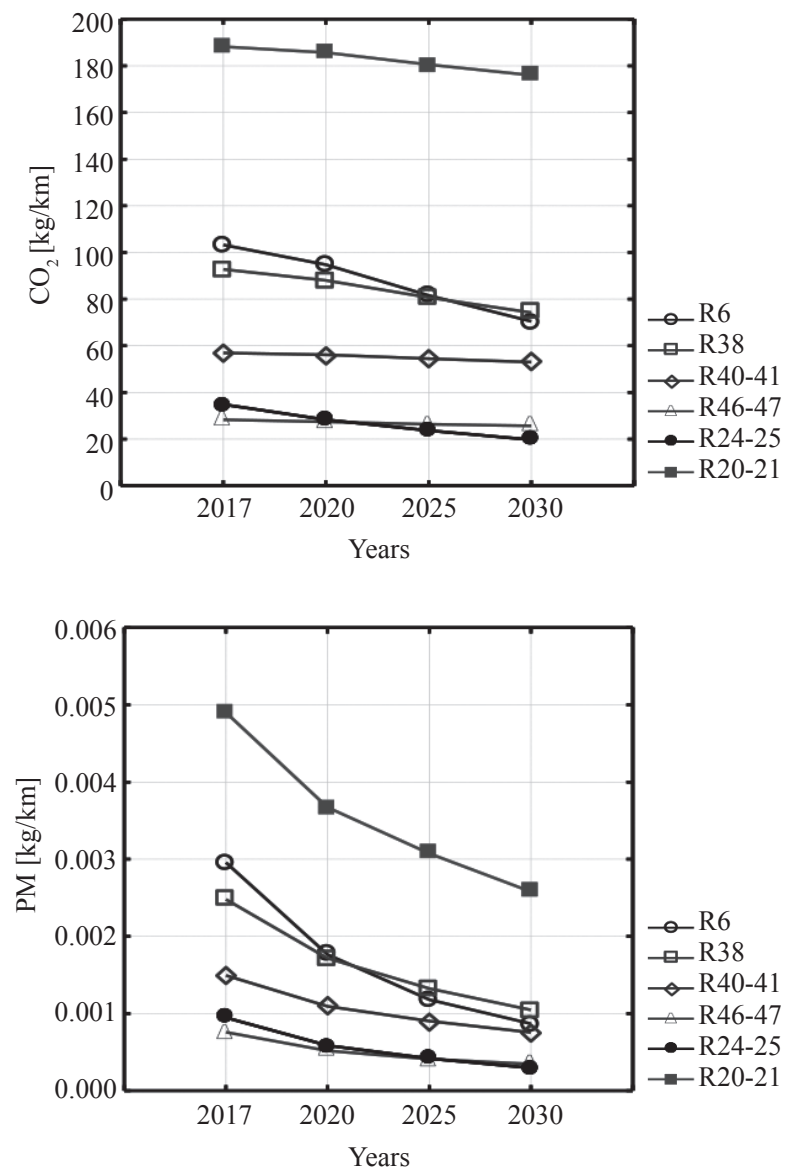

Figure 4-Calculated vehicle emissions results for a defined time period (in $\mathrm{kg} / \mathrm{km}$ per hour) 
significant decrease by $62.08 \%$ in relation to 2017 . The PM values in 2030 would decrease by $53.95 \%$ in relation to 2017, which represents an annual decrease of $5.79 \%$. The emphasis was placed on the interpretation of results of the roads R20-21 and R46-47 to show the extreme results obtained, which may be attributed not to the changes in the structure of the vehicle fleet in the observed period, but to the previously mentioned changes in the share of motor fuels and raising the standards of motor vehicles in the effort to minimize vehicle emissions.

\section{CONCLUSION}

Each year, certain countries in the area of the European Union, including the Republic of Croatia, record increased rates of motor vehicle numbers, mostly passenger cars, which considerably enhances the negative impact caused by the vehicle emissions. However, the measures defined by the European Union and the instruments it provided aim to increase the cooperation and efforts of all member countries in the drastic reduction of vehicle emissions. Precisely owing to that, the Republic of Croatia has fully accepted the Covenant of Mayors and has applied the proscribed measures to most cities. Owing to the Covenant, which was also implemented in the city of Rijeka, the vehicle emission values were identified at city level, i.e., six roads on which the greatest number of criteria defined to determine the coverage of the research were established by means of the designed traffic model and the conducted simulation.

The research results for the initial year 2017 singled out the road R20-21 as one of the roads on which the greatest amount of vehicle emissions was realized through the traffic of motor vehicles. By implementing the measures for the reduction of the share of certain vehicle categories (particularly passenger cars), the greater use of motor vehicles with hybrid or exclusively electrical drive, and gradual removal of vehicles that do not satisfy the latest standards of emission reduction would greatly improve the overall image of the current negative condition of vehicle emission concentrations in the city of Rijeka. If the mentioned improvement measures are taken and implemented by 2030 , there would be an average reduction of $\mathrm{CO}, \mathrm{CO}_{2}, \mathrm{NO}_{\mathrm{x}}$, and $\mathrm{PM}$ on each of the observed roads by $57.38 \%, 19.61 \%, 65.03 \%$, and $58.09 \%$, respectively, in relation to the reference year 2017. Finally, the authors estimate that according to the results obtained through the COPERT methodol- ogy, the city of Rijeka will positively respond to the requirements of the reduction measures for vehicle emissions proscribed by the European Union.

\section{Doc. dr. sc. LIVIA MAGLIĆ ${ }^{1}$}

E-mail: livia@pfri.hr

TOMISLAV KRLJAN, mag. ing. traff. ${ }^{1}$

E-mail: tomislav.krljan@uniri.hr

Izv. prof. dr. sc. NEVEN GRUBIŠIĆ ${ }^{1}$

E-mail: neven.grubisic@uniri.hr

Doc. dr. sc. LOVRO MAGLIĆ 1

E-mail:maglic@pfri.hr

${ }^{1}$ Sveučilište u Rijeci, Pomorski fakultet

Studentska 2, 51000 Rijeka, Hrvatska

\section{PROCJENA EMISIJA ŠTETNIH PLINOVA IZ CESTOVNIH VOZILA NA PROMETNICAMA U GRADU RIJECI}

Povećana potražnja za uslugama privatnog $i$ javnog prijevoza u urbanim sredinama zahtjeva kompleksan pristup u cilju ostvarenja zadovoljavajuće razine urbane mobilnosti. Jedan od osnovnih problema urbanih sredina su prometna zagušenja, a posljedično tome i emisije štetnih plinova. Cilj ovog rada je predložiti metodološki pristup procjene emisije štetnih plinova iz vozila. Predložena metodologija temelji se na dva međusobno povezana modela. Prvi model predstavlja mikroskopski simulacijski SUMO model temeljem kojega se identificiraju najzagušenija urbana područja te prometnice sa kritičnim vrijednostima prometnih parametara. Drugi model predstavlja COPERT Street Level model pomoću kojeg su procijenjene vrijednosti emisija štetnih plinova. Predloženi modeli testirani su na primjeru urbanog područja grada Rijeke. Rezultati mikroskopskog simulacijskog SUMO modela ukazuju na šest urbanih prometnica gdje su zabilježena najveća zagušenja odnosno kritične vrijednosti definiranih prometnih parametara. Na temelju identificiranih prometnica provedena je procjena emisija štetnih plinova za karakteristična vremenska razdoblja: 2017., 2020., 2025., i 2030. godina. Sukladno rezultatima primjene drugog modela, prometnica $20-21$ identificirana je kao najzagađenija s obzirom na detektirane razine štetnih emisija. Rezultati ukazuju da će se u periodu od 2017. do 2030. godine štetne emisije CO reducirati za prosječno $57 \%$ na svim identificiranim prometnicama, emisije $\mathrm{CO}_{2}$ za $20 \%$, emisije PM za 58\% dok je najveća redukcija u vrijednosti od $65 \%$ zabilježena kod emisije $\mathrm{NO}_{x}$

\section{KLJUČNE RIJEČI}

mikroskopski SUMO model; COPERT Street Level model; procjena štetnih emisija; održivi urbani promet.

\section{REFERENCES}

[1] Liu J, Han K, Chen X, Ong G-P. Spatial-temporal inference of urban traffic emissions based on taxi trajectories 
and multi-source urban data. Transportation Research Part C: Emerging Technologies. 2019;106: 145-165. DOI: $10.1016 / j . t r c .2019 .07 .005$

[2] The Intergovernmental Panel on Climate Change (IPCC). AR5 Climate Change 2014: Mitigation of Climate Change. Chapter 8 - Transport; 2014. Available from: http://www.ipcc.ch/ [Accessed 1st Nov. 2019].

[3] Wang H, Zeng W. Revealing Urban Carbon Dioxide $\left(\mathrm{CO}_{2}\right)$ Emission Characteristics and Influencing Mechanisms from the Perspective of Commuting. Sustainability. 2019;11(2): 385. DOI: 10.3390/su11020385

[4] Bakker S, Haq G, Peet K, Gota S, Medimorec N, Yiu, A, Jennings G, Rogers J. Low-Carbon Quick Wins: Integrating Short-Term Sustainable Transport Options in Climate Policy in Low-Income Countries. Sustainability. 2019;11(16): 4369. DOI: 10.3390/su11164369

[5] Zhang W, Lu J, Zhang Y. Moving towards Sustainability: Road Grades and On-Road Emissions of Heavy-Duty Vehicles-A Case Study. Sustainability. 2015;7: 1264412671. DOI: 10.3390/su70912644

[6] Ntziachristos L, Gkatzoflias D, Kouridis C, Samaras Z. COPERT: A European Road Transport Emission Inventory Model. Environmental Science and Engineering. 2009: 491-504. DOI: 10.1007/978-3-540-88351-7 37

[7] Gualtieri G, Camilli F, Cavaliere A, et al. An integrated low-cost road traffic and air pollution monitoring platform to assess vehicles air quality impact in urban areas. Transportation Research Procedia. 2017;27: 609-616. DOI: 10.1016/j.trpro.2017.12.043

[8] Park J, Noland R, Polak J. Microscopic Model of Air Pollutant Concentrations: Comparison of Simulated Results with Measured and Macroscopic Estimates. Journal of the Transportation Research Board. 2001;1750(1): 6473. DOI: $10.3141 / 1750-08$

[9] Smit R, Ntziachristos L, Boulter P. Validation of road vehicle and traffic emission models $-\mathrm{A}$ review and meta-analysis. Atmospheric Environment. 2010;44(25): 2943-2953. DOI: 10.1016/j.atmosenv.2010.05.022

[10] Beckx C, Panis L-I, Vankerkom J, Janssens D, Wets G, Arentze T. An Integrated Activity-Based Modelling Framework to Assess Vehicle Emissions: Approach and Application. Environment and Planning B: Planning and Design. 2009;36(6): 1086-1102. DOI: 10.1068/b35044

[11] Federal Register. Official Release of EMFAC 2017 Motor Vehicle Emission Factor Model for Use in the State of California, 2017. Available from: https://www.federalregister.gov/documents/2019/08/15/2019-17476/official-release-of-emfac2017-motor-vehicle-emission-factor-model-for-use-in-the-state-of-california [Accessed 9th Nov. 2019].

[12] Abou SH, Radwan S, Westerlund K, Cooper D. Using a traffic simulation model (VISSIM) with an emissions model (MOVES) to predict emissions from vehicles on a limited-access highway. Journal of the Air and Waste Management Association. 2013;63(7): 819-831. DOI: $10.1080 / 10962247.2013 .795918$

[13] Hirschmann K, Zallinger M, Fellendorf M, Hausberger
S. A new method to calculate emissions with simulated traffic conditions. $13^{\text {th }}$ International IEEE Annual Conference on Intelligent Transportation Systems, Portugal; 2010. p. 33-38. DOI: 10.1109/ITSC.2010.5625030

[14] Song G, Yu L, Zhang Y. Applicability of Traffic Microsimulation Models in Vehicle Emissions Estimates: Case Study of VISSIM. Journal of the Transportation Research Board. 2012;2270(1): 132-141. DOI: 10.3141/2270-16

[15] Stathopoulos FG, Noland RB. Induced Travel and Emissions from Traffic Flow Improvement Projects. Journal of the Transportation Research Board. 2003;1842(1): 5763. DOI: $10.3141 / 1842-07$

[16] Simulation of Urban Mobility. Passenger Car and Heavy Duty Emission Model. Available from: https://sumo.dlr. de/docs/Models/Emissions/PHEMlight.html [Accessed 19th Nov. 2019]

[17] The Handbook of Emission Factors for Road Transport. Available from: https://www.hbefa.net/e/index.html [Accessed 19th Nov. 2019].

[18] Papson A, Hartley S, Kuo KL. Analysis of Emissions at Congested and Uncongested Intersections with Motor Vehicle Emission Simulation 2010. Journal of the Transportation Research Board. 2012;2270: 124-131. DOI: 10.3141/2270-15

[19] European Environment Agency. COPERT III: Computer programme to calculate emissions from road transport. Available online: https://www.eng.auth.gr/mech0/lat/copert/C3v2_1MR.pdf [Accessed 13th Nov. 2019].

[20] Forehead H, Huynh N. Review of modelling air pollution from traffic at street-level - The state of the science. Environmental Pollution. 2018;241: 775-786. DOI: 10.1016/j.envpol.2018.06.019

[21] Primorsko-goranska County. Population. Available from: https://www.pgz.hr/Nas_kraj/Stanovnistvo [Accessed 1st Dec. 2019].

[22] Croatian Bureau of Statistics. Statistical Yearbook of the Republic of Croatia. Available from: https://www.dzs.hr/ [Accessed 3rd Dec. 2019].

[23] Department of City Administration for development, urbanism, ecology and land management. Spatial Plan of City of Rijeka. Available from: https://www.rije$\mathrm{ka} . \mathrm{hr} / \mathrm{teme}-\mathrm{za}$-gradane/stanovanje-i-gradnja/urbanisticko-planiranje-2/prostorni-planovi/prostorni-plan-uredenja-grada-rijeke/ [Accessed 4th Dec. 2019].

[24] Traffic Control Center Rijeka promet d.d. Road Categorization. Available from: http://www.rijekapromet.hr/hr/ kategorizacija_cesta/433/69 [Accessed 1st Dec. 2019].

[25] Centar za vozila Hrvatske (Department of Motor Vehicles). Available from: https://www.cvh.hr/naslovnica/ [Accessed 5th Dec. 2019].

[26] Primorsko-goranska County Police Administration. Available from: https://primorsko-goranska-policija.gov. hr/ [Accessed 5th Dec. 2019]. 